\title{
Effects of Production Costs and Operating Costs on Profit of PT Semen Baturaja (Persero) Tbk
}

\author{
Fasya Nadiah' ${ }^{1)}$ RM Rum Hendarmin ${ }^{2)}$ Vhika Meiriasari ${ }^{3)}$ \\ 1), 2), 3) Universitas Indo Global Mandiri, Palembang, Indonesia \\ Email: fasyanadiah24@gmail.com ${ }^{1)}$,hendarmin@uigm.ac.id ${ }^{2}$,vhikams@uigm.ac.id ${ }^{3)}$
}

\begin{abstract}
The objectives of this research are to determine the effect of production costs and operating costs on company profits at PT. Semen Baturaja (Persero) Tbk. The data investigated is an annual income statement for the period 2012 - 2019. The data is then analyzed using multiple linear regression. Further statistical tests revealed the variable production costs do not have a positive effect on company profits, but on the other hand, business costs have a positive effect on company profits. Furthermore, the coefficient of determination (R2) obtained a value of 0.890 . This means that the variable production costs and business costs can explain the company's profit by $89 \%$ the rest is influenced by other variables not included in this study.
\end{abstract}

Keywords: production costs, business costs, company profits

\section{Introduction}

Companies have an important role in economic development because they are one of the active contributors to state revenue. Currently, the business world is growing very rapidly. The increasingly fierce competition in the business world to maintain and improve its business shows this. In order to develop, companies must go through stages and be supported by effective plans to resolve various problems and constraints, such as operational, financial and product marketing problems. (Susilawati, 2019)

Production costs are costs incurred to process raw materials into finished products that are ready to be sold. These costs consist of raw material costs, direct labor costs, and factory overhead costs. Basically, the problem that often arises is that the cost planning is not in accordance with what is actually happening (realization). Therefore, to be able to achieve efficient production, it is necessary to control production costs that will be incurred and production costs affect net income. (Susilawati, 2019)

Business costs are one of the most important elements to determine the profitability and feasibility of a business. Then we need to calculate in more detail. To calculate business costs, three methods are used, namely benefit-cost ratio, investment payback period, and break-even point, which will calculate various costs in more detail such as marketing costs, selling costs, and administrative costs. Errors in calculating business costs will result in not maximizing profits to be obtained by the company which will also affect policies to determine business feasibility. (Friskilla, 2017)

Profit is the excess of income over costs for one accounting period (Harahap, 2011). Meanwhile, the understanding of profit adopted by the current accounting structure is the difference between the measurement of income and costs. Based on some of these definitions, it can be concluded that profit is a positive difference as a result of selling products and services at a price higher than the cost to produce these products or services. (Sayyida, 2015)

PT Semen Baturaja (Persero) Tbk is a company engaged in the cement processing industry in 
South Sumatra. The company has invested considerable energy in achieving its main objectives (i.e. producing high quality, high efficiency cement, and marketing with customer satisfaction first, and must earn the best profit), and strives to deal with the company accurately. income and expenses. The company's main revenue comes from cement sales, while the company's expenses come from company operations. Most of the company's sales or transactions are made in cash and used for redemption. Distributor Cement Letter of Credit Redeemer must provide a guarantee with a bank guarantee or other form of guarantee.

The company runs production located in Baturaja, South Sumatra. Meanwhile, the cement milling and bagging process is carried out at the Baturaja Factory, Palembang Factory and Panjang Factory which are then distributed to the Company's marketing areas. The raw materials for the Company's cement products are limestone and clay obtained from the Company's limestone and clay mining sites, which are located about $1.2 \mathrm{~km}$ from the factory in Baturaja. Other supporting raw materials such as silica sand are obtained from partners around the Baturaja area; iron sand obtained from partners in the province of Lampung; Gypsum is obtained from Petro Kimia Gersik or imported from Thailand; while cement bags are obtained from manufacturers of finished bags which are sold domestically.

In the cost leadership plan, the company achieves cost efficiencies in various areas of operations, administration and public areas, and sales areas, such as reducing familiarity by optimizing the use of hazardous waste, using cheaper energy, tightening budget regulations, and reducing costs. Material factor. General and administrative expenses and selling expenses. This has an impact on the low cost of cement production, so that the company is able to compete with competitors who apply predatory pricing practices. In addition, the company can also get a higher profit margin

Table 1. Company Data PT. Semen Baturaja (Persero) Tbk

\begin{tabular}{|c|c|c|c|c|c|c|c|}
\hline Year & $\begin{array}{c}\text { Sales } \\
\text { Volume }\end{array}$ & Net sales & $\begin{array}{c}\text { Production } \\
\text { cost }\end{array}$ & $\begin{array}{c}\text { Gross } \\
\text { profit }\end{array}$ & $\begin{array}{c}\text { Business } \\
\text { costs }\end{array}$ & $\begin{array}{c}\text { Operating } \\
\text { profit }\end{array}$ & Net profit \\
\hline 2012 & 1.233 .933 & 1.097 .680 & 608.022 & 489.835 & 11.994 & 367.132 & 298.512 .522 \\
\hline 2013 & 1.262 .386 & 1.168 .608 & 718.792 & 462.208 & 9.504 & 329.178 & 312.183 .833 \\
\hline 2014 & 1.262 .707 & 1.214 .915 & 839.367 & 372.461 & 5.595 & 253.294 & 335.954 .862 \\
\hline 2015 & 1.538 .048 & 1.461 .248 & 967.249 & 493.579 & 13.575 & 323.263 & 345.180 .061 \\
\hline 2016 & 1.631 .864 & 1.522 .806 & 1.008 .039 & 510.998 & 50.804 & 328.421 & 259.086 .871 \\
\hline 2017 & 1.762 .137 & 1.551 .525 & 1.086 .782 & 472.818 & 85.403 & 192.096 & 146.643 .510 \\
\hline 2018 & 2.189 .357 & 1.995 .808 & 1.297 .455 & 706.645 & 181.053 & 247.502 & 76.071 .972 \\
\hline 2019 & 2.119 .772 & 1.999 .772 & 1.133 .415 & 874.889 & 341.702 & 233.944 & 30.072 .337 \\
\hline
\end{tabular}

Based on the table 1, it can be seen that the results of production costs, operating costs and net profit fluctuate (up and down) every year. It can be seen that production costs in 2019 amounted to $2,119,772$, there was a decrease while in 2018 there was an increase of $1,2987,455$. Business costs in 2019 amounted to 341,702 an increase while in 2014 amounted to 5,595 there was a decrease. Net profit in 2019 was 30,072,337, there was a decrease, while in 2016 it was $345,180,061$ there was an increase. 
Based on the data above, the researcher is interested in conducting research and presenting it in the form of a thesis with the title Analysis of the Effect of Production Costs and Business Costs on Company Profits at PT. Semen Baturaja (Persero) Tbk Palembang.

\section{Literature Review}

\subsection{Production Cost}

Production costs are costs incurred in managing raw materials into products, which are used to calculate the cost of finished products and product costs which at the end of the accounting period are still in process. production costs is the sum of raw material costs plus direct labor costs and factory overhead costs

\subsection{Operating Expenses}

Costs incurred to produce and market goods as well as general administrative costs

\section{Marketing Cost}

According to Mulyadi (2018: 487), "In a broad sense, marketing costs include all costs incurred from the time the product is finished being produced and stored in the warehouse until the product is converted back into cash."

\section{Sales}

Sales is one of the operational activities of the cooperative, besides that sales are also one of the main objectives of the cooperative. Sales is an important part, both for industrial companies, trading companies and cooperatives. "Selling is an activity aimed at finding buyers, influencing, and giving instructions so that buyers can adjust their needs to the production offered and enter into agreements regarding prices that are beneficial for both parties." (Putranto, 2017) "Sales are an income transaction in which goods or services are sent by a customer in exchange for cash, an obligation to pay."

\section{Administration Fee}

"Administrative and general costs are costs to coordinate production and product marketing activities. Examples of these costs are the cost of employee salaries in finance, personnel accounting and public relations, accountant examination fees and photocopy costs. defines administrative and general costs briefly, namely "administrative and general costs, namely all costs associated with general administrative functions"

\subsection{Corporate profits}

In his opinion, net income is stated, which is the difference between all income and profits over all costs and losses. This amount represents a net increase in capital" (Januarsah et al., 2019). Factors that affect the amount of profit earned are as follows:

1. Costs, namely costs arising from the acquisition or processing of a product or service will affect the selling price of the product in question.

2. Selling price, namely the selling price of the product or service will affect the volume of sales of the product or service concerned.

3. Sales and production volume, the amount of sales volume affects the volume of production (services). And the volume of production will affect the size of the cost of production.

\subsection{Research Framework}


The research conceptual framework explains the relationship between the variables to be tested, namely the analysis of production costs and operating costs on company profits at PT. Semen Baturaja (Persero) Tbk. The research concept framework can be seen in the figure below:

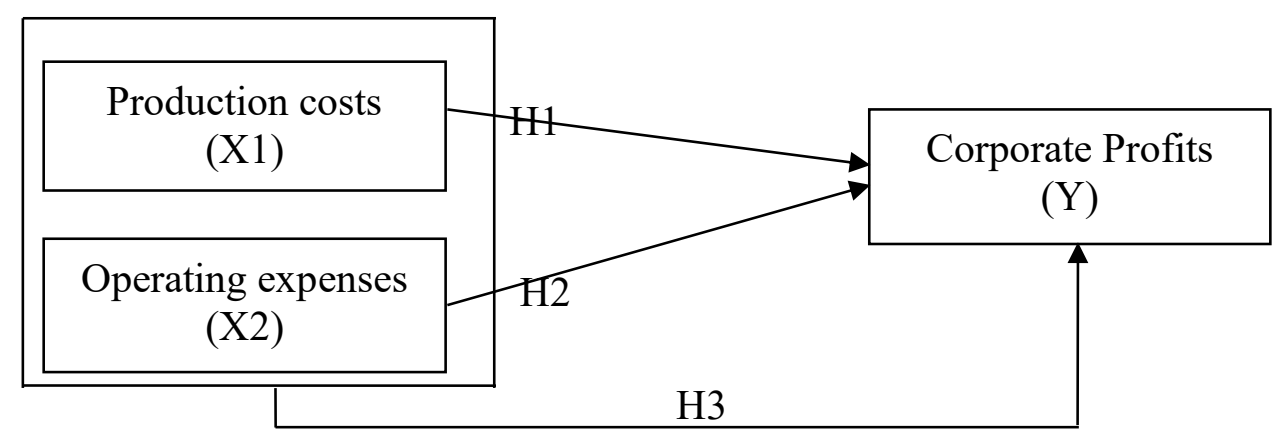

Figure 1. Framework

\subsection{Hypothesis}

H1 : Production costs affect the profit of PT. Baturaja Cement

$\mathrm{H} 2$ : Operating expenses affect the profit of the company PT. Baturaja Cement

H3 : Production Costs and Operating Costs affect the Profit of PT. Semen Baturaja

\section{Research Method}

The data used in this study is a type of secondary data. Secondary data itself is data obtained from certain sources that are already available. Sources that do not directly provide data on data collection. Data in this study was obtained from the annual income statement data of the company PT. Semen Baturaja (Persero) Tbk Palembang in 2012 - 2019. The data analysis method used in this research is descriptive quantitative analysis method and qualitative descriptive analysis, classical assumption test (normality test, multicollinearity test, heteroscedasticity test, autocorrelation test), and hypothesis test (test $\mathrm{t}$ and $\mathrm{F}$ test).

\section{Findings and Discussions}

4.1 Hypothesis Testing Results

Tabel 2. t-Test Result

\section{Coefficients $^{\mathrm{a}}$}

\begin{tabular}{|c|c|c|c|c|c|c|}
\hline & & \multicolumn{2}{|c|}{ Unstandardized Coefficients } & $\begin{array}{l}\text { Standardized } \\
\text { Coefficients }\end{array}$ & \multirow[b]{2}{*}{$\mathrm{T}$} & \multirow[b]{2}{*}{ Sig. } \\
\hline \multicolumn{2}{|c|}{ Model } & B & Std. Error & Beta & & \\
\hline & (Constant) & 434063050643,417 & 96067746330,027 & & 4,518 &, 006 \\
\hline & $\begin{array}{l}\text { Production } \\
\text { costs (X1) }\end{array}$ & $-147,578$ & 110,885 &,- 270 & $-1,331$ & ,241 \\
\hline & $\begin{array}{l}\text { operating } \\
\text { costs (X2) }\end{array}$ & $-769,662$ & 211,483 &,- 738 & $-3,639$ &, 015 \\
\hline
\end{tabular}

a. Dependent Variable: Company Profit 
Meanwhile, the significance value of tcount variable Production Cost is 0.241 , meaning $>0.05$. Based on these results, the production costs have no effect on the company's profit. $\mathrm{H} 1=$ rejected. The result of $t$-calculated Business Costs is -3.639 while $t$-table $=2.570$, then the value of t-count $>\mathrm{t}$-table. Meanwhile, the significance value of $\mathrm{t}$-count variable operating costs is 0.015 , meaning $<0.05$. Based on these results, the operating costs affect the company's profit. $\mathrm{H} 2=$ accepted.

Table 3. F Test Results

ANOVA $^{\mathrm{a}}$

\begin{tabular}{|c|c|c|c|c|c|c|}
\hline \multicolumn{2}{|c|}{ Model } & Sum of Squares & $\mathrm{df}$ & Mean Square & $\mathrm{F}$ & Sig. \\
\hline & Regression & $\begin{array}{r}95432525129346510000 \\
000,000\end{array}$ & 2 & $\begin{array}{r}47716262564673255000 \\
000,000\end{array}$ & 20,213 &, $004^{b}$ \\
\hline & Residual & $\begin{array}{r}11803103681237391000 \\
000,000\end{array}$ & 5 & $\begin{array}{r}23606207362474784000 \\
00,000\end{array}$ & & \\
\hline & Total & $\begin{array}{r}10723562881058390000 \\
0000,000\end{array}$ & 7 & & & \\
\hline
\end{tabular}

a. Dependent Variable: Company Profit (Y)

b. Predictors: (Constant), Operating Cost (X2), Production Cost (X1)

Based on table 3, it can be seen that the calculated F results show a value of 20.213 , which means it is greater than the $\mathrm{F}$ table, which is 5.79 with a significance value of $0.004<0.05$. This shows that the regression model can be used to predict the variables of production costs and operating costs on company profits or it can be said that there is a simultaneous influence between production costs and operating costs on company profits. $\mathrm{H} 3=$ accepted.

\subsection{Discussion}

Production costs partially have no significant negative effect on company profits at PT. Semen Baturaja (Persero) Tbk for the period 2012-2019 with a t-count of production costs of -1.331 while $\mathrm{t}$-table $=2.570$, then the value of $\mathrm{t}$-count $<\mathrm{t}$-table. Meanwhile, the significance value of $\mathrm{t}$ count variable production cost is 0.241 , meaning $>0.05$. Based on these results, the production costs have no effect on the company's profit. $\mathrm{H} 1$ = rejected. The results are negative, meaning that there is a negative relationship between production costs and company profits, which means that the higher the production costs, the lower the company's profits. The results of this study are in accordance with Jannah (2018: 99-100) which states that gross profit is obtained from reducing sales with cost of goods sold. So it can be said that production costs are a reduction in gross profit because production costs reduce income or it can be said that production costs have a negative effect on gross profit. This means that if production costs increase, while other elements remain constant, then gross profit tends to fall. Production costs at PT. Semen Baturaja (Persero) Tbk consists of the cost of raw and auxiliary materials, direct labor costs and factory overhead costs

Operating costs partially have a significant negative effect on company profits at PT. Semen Baturaja (Persero) Tbk for the 2012-2019 period with the result of t-count Operating Costs of 3.639 while $\mathrm{t}$-table $=2.570$, then the value of $\mathrm{t}$-count $>\mathrm{t}$-table. Meanwhile, the significance value of $\mathrm{t}$-count variable operating costs is 0.015 , meaning $<0.05$. Based on these results, the 
operating costs affect the company's profit. $\mathrm{H} 2$ = accepted. The results are negative, meaning that there is a negative relationship between operating costs and company profits, which means that the higher the operating costs, the lower the company's profits. The business costs at PT. Semen Baturaja (Persero) Tbk in the form of marketing costs, sales, import costs, vehicle depreciation, vehicle spare parts, entertainment and advertising. Business costs can increase the increase in net income, because all costs incurred for marketing activities are to support sales activities, so that the business costs incurred cause an increase in sales volume which ultimately affects the increase in net profit.

Production costs and operating costs simultaneously affect the company's profit at PT. Semen Baturaja (Persero) Tbk Period 2012-2019 with $\mathrm{F}$ count $=12.788>\mathrm{F}$ table $=3.28$ and significant $0.000<0.05$ and the result of the coefficient of determination test is $89 \%$ of the variation of the company's profit variable which can be explained by the independent variable production costs and business costs. The magnitude of the effect of production costs and operating costs on company profits by $89 \%$ the rest is influenced by other factors that are not used in this study. Thus H3 which states production costs and operating costs affect the company's profit at PT. Semen Baturaja (Persero) Tbk period 2012-2019 can be accepted. By looking at the value of the regression coefficient and the significance value, it can be seen that the operating cost variable has a more dominant effect on profits at PT. Semen Baturaja (Persero) Tbk for the period 2012-2019.

\section{References}

Daslim, F., Harahap, S. and Elidawati (2019) 'Pengaruh Biaya Produksi dan Biaya Pemasaran terhadap Laba pada PT. Sumatera Hakarindo Medan', jurnal Bisnis Kolega, 5(2), pp. 7083.

Dewi, S. R. (2019). Pengaruh Biaya Produksi Terhadap Harga Jual Pada Pt Shamrock Manufacturing Corporation. Magisma: Jurnal Ilmiah Ekonomi dan Bisnis, 5(1), pp. $57-$ 63. doi: 10.35829/magisma.v5il.12.

Fathony, A. A. D. R. Y. T. R. (2016). Pengaruh Biaya Administrasi Dan Umum Terhadap Laba Operasional Pada PT. Adhi Karya Tbk (Studi Empiris Pada Salah Satu Perusahaan yang Terdaftar di Bursa Efek Indonesia)', 7(April), pp. 1-8.

Friskilla, D. (2017) 'Analisis Biaya Usaha Menggunakan Metode Benefit Cost Ratio, Pay Back Period, Break Even Point Untuk Mengetahui Tingkat Keuntungan Dan Kelayakan Usaha Pada Usaha Peternakan Ayam Potong (Broiler) Di Ds. Bedali Kec. Ngancar Kab. Kediri', Simki-Economic, 01(02).

Halin, H. (2018). Pengaruh Kualitas Produk Terhadap Kepuasan Pelanggan Semen Baturaja Di Palembang Pada PT Semen Baturaja (Persero) Tbk. Jurnal Ecoment Global, 3(2), p. 79. doi: $10.35908 /$ jeg.v3i2.477.

Januarsah, I. et al. (2019). Pengaruh Biaya Produksi Dan Biaya Pemasaran Terhadap Laba Perusahaan Pada PT PP London Sumatera Indonesia,Tbk Yang Terdaftar Di Bursa Efek Indonesia', Financial: Jurnal Akuntansi, 5(1), pp. 32-39. doi: 10.37403/financial.v5i1.90.

Putranto, A. (2017) 'Analisis Pengaruh Biaya Produksi dan Penjualan Terhadap Laba Perusahaan (Studi Pada Usaha Mikro Kecil Dan Menengah Di Kecamatan Wonosobo Kabupatenwonosobo)', Jurnal Penelitian dan Pengabdian Kepada Masyarakat UNSIQ, 4(3), pp. 280-286. doi: 10.32699/ppkm.v4i3.432.

Sayyida (2015) 'Pengaruh Biaya Produksi Terhadap Laba Perusahaan Studi Kasus Pabrik 
Kecap Kelapa Muda UD. Surya Mandala Putra Gapura Sumenep Dosen Fakultas Ekonomi Universitas WIraraja', Jurnal Performance Bisnis dan Akuntansi, IV(1), pp. $1-13$.

Sembiring, M. (2018) 'Pengaruh Biaya Produksi Dan Biaya Pemasaran Terhadap Laba Bersih', Jurnal Studi Akuntansi \& Keuangan, 2(3), pp. 135-140.

Susilawati, E. (2019) 'Susilawati : Pengaruh Biaya Produksi dan Biaya Promosi Terhadap Laba Bersih (Studi Perusahaan Rokok PT Gudang Garam Tbk Yang Terdaftar di BEI Periode 2011 - 2017)', Manners, Vol.II, No(1), pp. 25-39. Available at: http://jurnal.unnur.ac.id/index.php/manners/search/search. 